\title{
THE IMPACT OF KNOWLEDGE CAPTURE AND KNOWLEDGE SHARING ON LEARNING, ADAPTABILITY, JOB SATISFACTION AND STAYING INTENTION: A STUDY OF THE BANKING INDUSTRY IN BANGLADESH
}

\author{
Zahid Zamir \\ Delaware State University \\ Dover-19901, DE, USA \\ zzamir@desu.edu
}

\begin{abstract}
The Knowledge Management (KM) has been defined as performing activites in discovering, capturing, sharing and applying knowledge in a more effective and effieicnt way. This study looks at only two such processes namely: capruring and sharing knowledge and their sub-processes. The purpose of this study is to conduct exploratory research to investigate the extent to which the sub-processes of knowledge capture and knowledge sharing of knowledge management impact the employee learning, adaptability, Job satisfaction and intention to stay on the job. This research was conducted using a purposive sample from financial services firms in Bangladesh. The sample consisted of 254 respondents from 23 different branches of eight commercial banks drawing from all levels of employees in the organizational hierarchy. The partial least squares (PLS) approach using Smart PLS has been used to test both the measurement and structural models. The findings of this study confirm that it is not the KM processes rather the sub-processes of KM process that can positively impact on employees' outcomes. This study involved self-administrated questionnaires and was open to all levels of staff and measured perceptions of the employees as opposed to actual behavior. This study suggests that employees' learning and adaptability depend on the usability and comfortability of the knowledge management initiatives undertaken by the management. Practitioners may employ the same experimental method using the instruments developed for this study to analyze the impact of the sub-processes of knowledge capture and knowledge sharing on employee outcomes. This study contributes to the existing literature of knowledge management that how the sub-processes of knowledge capture and knowledge sharing motivate employees to learn and adapt and how learning and adaptability contribute to job satisfaction and staying intention.
\end{abstract}

KEYWORDS: Knowledge capture, knowledge sharing, employee learning, employee adaptability, job satisfaction, intention to stay.

JEL CLASSIFICATION: D83, J28, J64

DOI: $10.2478 /$ IJEK-2019-0004

Received: April 12 2019.

1st Revision: April 30 2019.

Accepted: May $15^{\text {th }} 2019$

Reference: Zamir, Z (2019). The Impact of Knowledge Capture and Knowledge Sharing on Learning, Adaptability, Job Satisfaction and Staying Intention. International Journal of Entrepreneurial Knowledge, 7(1), 46-64. doi: 10.2478/ijek-2019-0004

\section{INTRODUCTION}

Knowledge Management (KM) is not entirely a new concept. It has progressed from a new idea to an increasingly common function in business organizations and has been the subject of several studies in various settings as companies seek more effective ways of increasing organizational capability for competitive advantage (Zack, 1999). Knowledge Management focuses on organizing and making available essential knowledge, wherever and whenever it is needed. Becerra-Fernandez et al. (2004) have described four types of KM processes such as Knowledge Discovery, Knowledge Capture, Knowledge Sharing, and Knowledge Application. Each of the four sets of KM Processes proposed by Becerra-Fernandez et al. (2004) consists of sub-processes. The sub-processes of combination and 
socialization enable knowledge discovery. In Combination, we can combine existing knowledge to create new knowledge, and through Socialization subprocess, tacit knowledge is combined with interactions between individuals and groups to develop new knowledge. Knowledge Capture can take place through externalization and Internalization.

In externalization, tacit knowledge is converted to explicit knowledge, and through internalization subprocess, explicit knowledge is converted into tacit knowledge. Knowledge sharing can happen through socialization and exchange. Through Socialization, sub-process tacit knowledge is shared or transferred between individuals and through exchange subprocess, explicit knowledge is transferred between individuals. Knowledge sharing can take place across individuals, groups, departments, or organizations. Tacit knowledge is shared through socialization, and explicit knowledge is shared by the exchange process. Tacit knowledge forms the background necessary for assigning the structure to develop and interpret explicit knowledge. The inextricable linkage of tacit and explicit knowledge suggests that only individuals with a requisite level of shared knowledge can indeed exchange knowledge (Becerra-Fernandez et al., 2004). The knowledge application process takes place through the sub-process of direction and routines. Direction refers to the process through which individuals possessing the knowledge direct the action of another individual without transferring to that person the knowledge underlying the direction and Routines involve the utilization of knowledge embedded in procedures, rules, and norms that guide future behavior.

Knowledge management can impact an organization at different levels such as: impact on People in terms of employee learning, employee adaptability, and employee job satisfaction, impact on processes in terms of process effectiveness, efficiency and innovation, impact on Products in terms of value added products as well as knowledge-based products, all of which in turn impact organizational performance (Becerra-Fernandez et al., 2004). KM can affect employee learning through internalization, externalization, socialization, and exchange. Internalization and externalization subprocesses work together to help individuals learn. Socialization and exchange also help individuals acquire knowledge through meetings and informal conversations. As for the impact of KM on employee adaptability, employees are likely to adapt when they interact with each other. They are more likely to accept change. They are more prepared to respond to change. KM efforts are intended to expose employees to new ideas and employees continually are ready for change as they are in touch with latest ideas and developments and increased employee's adaptability die to KM enabled company to become a fast-changing organization. As for the impact of $\mathrm{KM}$ on jobs satisfaction and intention to stay, an organization having more employees sharing knowledge, turnover rates are reduced, thereby positively affecting revenue and profit. KM also provides employees with solutions to problems they face in case those same problems have been encountered earlier and adequately addressed. By enabling knowledge reuse, employees can be more productive. Employees facing problems in performing their jobs become de-motivated. Improvement in skills also increases its market value.

Although the implementation of knowledge management has been cited widely as a challenge in organizational effectiveness and performance, there is a little research on the broader aspects of the nature and means through which internalization and externalization sub-processes of knowledge capture, as well as socialization and exchange sub-processes of knowledge sharing, can impact on employee learning, adaptability and how employee learning and adaptability lead to job satisfaction and how job satisfaction leads to employees' intention to stay on the job.

With that in mind, this study has tried to examine the following:

1. Impact of internalization and externalization sub-processes of knowledge capture and socialization and exchange sub-processes of knowledge sharing on employee learning and adaptability.

2. Impact of employee learning and adaptability on employees' job satisfaction.

3. Impact of job satisfaction on employees' intention to stay. 


\section{RESEARCH MODEL, CONSTRUCTS AND HYPOTHESES}

The study of possible effects of introducing $\mathrm{KM}$ in the firms has centered on determining whether it can carry out quantifiable improvements. Marques and Simon (2006), Ho (2008), have discussed the relationship between KM, KM processes and performance of organizations at length. However, a study conducted by Zack et al. (2009) have found no direct relationship between KM and financial performance but KM to related to Organizational performance which in turn linked to financial performance. Studies undertook by Dibella and Navis (1998) Salazar et al. (2003), Singh et al. (2006), Lundvall and Nielsen (2007) examined the use of KM and the competitive advantages in an organization. They have demonstrated that organizations with knowledge management orientation outperformed organizations with market orientation and suggested that competitive advantage comes from the way organization performs knowledge activity. Sabherwal \& Becerra-Fernandez (2003), Yang (2007), Marques and Simon (2006), demonstrated that knowledge stock accumulate knowledge assets that are internal to the firm and knowledge sharing facilitates the transformation of the collective individual knowledge to organizational knowledge which results in the advancement of organizational learning and eventually the enrichment of organizational effectiveness. Boumarafi and Jbnoun (2008) stated some studies conducted by some authors (Skyrme and Amidon, 1997; King et. al.,; 2002; Hung et. al., 2005; Koh et.al., 2005; Mahnke et.al., 2005) who found evidence of a positive correlation with the successful implementation of knowledge management systems (KMS) in business organizations. Kianto et al. (2016), Teh \& Sun (2012), Lee-Kelley et al. (2007) studied how the implementation of KM processes help improve employees' job satisfaction and retention (Intention to stay). They have demonstrated through empirical studies how organizations that adopted KM initiatives were able to improve employees' job satisfaction and retention.

Based on the review of the prior literature, the following conceptual model is developed:

\section{Figure 1: Conceptual Model}

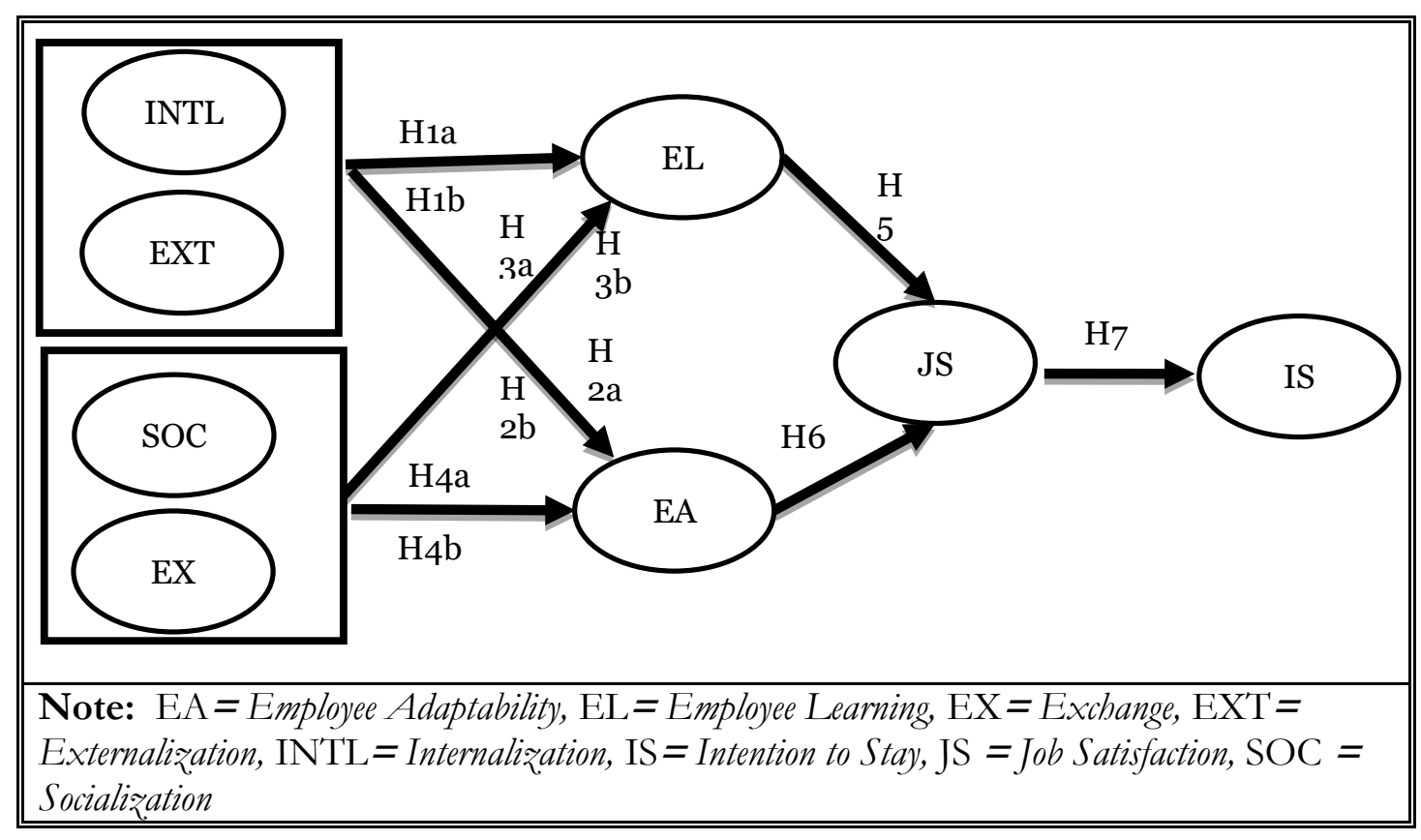




\begin{tabular}{|c|c|c|}
\hline Constructs & Items & Reference \\
\hline $\begin{array}{l}\text { Internalization: } \\
\text { The degree of tacit } \\
\text { knowledge } \\
\text { accumulation } \\
\text { through personal } \\
\text { experiences, } \\
\text { simulations, and } \\
\text { experimentation. }\end{array}$ & $\begin{array}{l}\text { INTL1: I believe learning by continuous self-refinement through } \\
\text { on the job training can help accumulate tacit knowledge } \\
\text { INTL2: I share and try to understand management visions } \\
\text { through communications with other employees } \\
\text { INTL3: I agree that learning by doing (which means that written } \\
\text { procedures and rules/practices have to be carried through } \\
\text { action), training and exercises allow the individual to access the } \\
\text { knowledge dominion of the organization. } \\
\text { INTL4: I collect tacit knowledge (Belief, perception, the point of } \\
\text { view) by increasing the use of formal knowledge (explicit } \\
\text { knowledge) in real life or computer-generated applications. } \\
\text { INTL5: I can use the knowledge repository } \\
\text { (Internet/Database/Library) to obtain knowledge for my job. }\end{array}$ & New \\
\hline $\begin{array}{l}\text { Externalization: } \\
\text { The degree of } \\
\text { articulating tacit } \\
\text { knowledge (Ideas or } \\
\text { images) in the form } \\
\text { of words, concepts, } \\
\text { visuals, or figurative } \\
\text { language. }\end{array}$ & $\begin{array}{l}\text { EXT1: I believe my organization recognize contradiction through } \\
\text { metaphor/symbol and resolve them through analogy. } \\
\text { EXT2: I agree with the notion that my organization encourages } \\
\text { dialogue, Listening and contributing to the benefit of all } \\
\text { participants' within the organization. } \\
\text { EXT3: I produce and document/record concepts in by screening } \\
\text { ideas from others. } \\
\text { EXT4: For the efficiency and effectiveness of my work, I record/ } \\
\text { document subjective opinions of other employees of my } \\
\text { organization. } \\
\text { EXT5: I capture and translate tacit knowledge (ideas, beliefs, } \\
\text { perception) of customers or experts into readily understandable } \\
\text { forms (write them down or record them). } \\
\text { EXT6: I create manuals/handbooks/booklets and documents on } \\
\text { products and services. }\end{array}$ & New \\
\hline $\begin{array}{l}\text { Socialization: } \\
\text { The degree of tacit } \\
\text { knowledge sharing } \\
\text { between individuals } \\
\text { through social } \\
\text { interaction related } \\
\text { to the task and task } \\
\text { efficiency. }\end{array}$ & $\begin{array}{l}\text { SOC1: I share the information and knowledge necessary for the } \\
\text { tasks. } \\
\text { SOC2: I improve task efficiency by sharing information and } \\
\text { knowledge. } \\
\text { SOC3: I promote the sharing of information and knowledge with } \\
\text { other teams in my organization } \\
\text { SOC4: I promote and organize brainstorming retreats or camps } \\
\text { for knowledge sharing to solve the problem } \\
\text { SOC5: I believe employee rotation across areas for knowledge } \\
\text { seeking and sharing should be encouraged. } \\
\text { SOC6: I believe employees from various functional units should } \\
\text { work together to achieve a common goal. }\end{array}$ & New \\
\hline
\end{tabular}




\begin{tabular}{|c|c|c|}
\hline $\begin{array}{l}\text { Exchange: } \\
\text { The degree of } \\
\text { sharing explicit } \\
\text { knowledge among } \\
\text { individuals, groups, } \\
\text { departments or } \\
\text { organizations. }\end{array}$ & $\begin{array}{l}\text { EX1: I use information systems, like intranet and electronic } \\
\text { bulletin boards developed by my organization to share } \\
\text { information and knowledge with other employees. } \\
\text { EX2: I use repositories of information (database), best practices, } \\
\text { and lessons learned to share explicit knowledge related to the } \\
\text { task. } \\
\text { EX3: I prefer to exchange explicit knowledge through } \\
\text { computerized communication networks (Social Media). } \\
\text { EX4: I am happy the way my organization uses Memos, manuals, } \\
\text { letters, and presentations to share information with employees. } \\
\text { EX5: My Company creates/produces materials by gathering } \\
\text { management figures and technical information to share with } \\
\text { employees. } \\
\text { EX6: I feel the need for reconfiguration of existing documents } \\
\text { through sorting, adding, combining and categorizing of explicit } \\
\text { knowledge. }\end{array}$ & New \\
\hline $\begin{array}{l}\text { Employee } \\
\text { Learning: } \\
\text { The degree of } \\
\text { opportunity, variety, } \\
\text { satisfaction, and } \\
\text { encouragement for } \\
\text { learning and } \\
\text { development in an } \\
\text { organization. }\end{array}$ & $\begin{array}{l}\text { EL1: I get various formal training programs for performance of } \\
\text { duties provided by my organization. } \\
\text { EL2: I receive informal individual development other than } \\
\text { formal training such as work assignments and job rotation } \\
\text { provided by my organization. } \\
\text { EL3: Employees are encouraged to seek professional } \\
\text { development (attending seminars, symposia, and so on). } \\
\text { EL4: I consider employees' development through learning as the } \\
\text { key to success rather than a cost to the organization. } \\
\text { EL5: I am continuously learning and trying to improve myself. }\end{array}$ & New \\
\hline $\begin{array}{l}\text { Employee } \\
\text { Adaptability: } \\
\text { Degree to which } \\
\text { employees accept } \\
\text { change based on } \\
\text { organizational } \\
\text { circumstances. }\end{array}$ & $\begin{array}{l}\text { EA1: I can take on new tasks. } \\
\text { EA2: I can step in for co-workers when needed. } \\
\text { EA3: I consider myself useful in adjusting to changes. } \\
\text { EA4: I am open to doing things in a new way. } \\
\text { EA5: My organization encourages employees to adjust to } \\
\text { changing situations through innovation and creativity. }\end{array}$ & New \\
\hline $\begin{array}{l}\text { Job Satisfaction : } \\
\text { Degree to which } \\
\text { employees' reaction } \\
\text { results from an } \\
\text { appraisal of one's } \\
\text { job situation. }\end{array}$ & $\begin{array}{l}\text { JS1: All things considered, I feel very satisfied when I think about } \\
\text { my job } \\
\text { JS2: I am made to believe that I am an essential part of the } \\
\text { company. } \\
\text { JS3: I have good working relationships with my co-workers. } \\
\text { JS4: I enjoy working in this organization. } \\
\text { JS5: My job is rewarding/ I get a sense of personal } \\
\text { accomplishment from my work. }\end{array}$ & $\begin{array}{l}\text { Hair et } \\
\text { al.(2010) }\end{array}$ \\
\hline $\begin{array}{l}\text { Intention to Stay : } \\
\text { The extent to which } \\
\text { an employee intends } \\
\text { to continue working } \\
\text { for an organization } \\
\text { and is not } \\
\text { participating in } \\
\text { activities that make } \\
\text { quitting more likely. }\end{array}$ & $\begin{array}{l}\text { IS1: I am not actively searching for another job. } \\
\text { IS2: I seldom look at the job listings online. } \\
\text { IS3: I have no interest in searching for a job in the next year. } \\
\text { IS4: It is very likely that I will be working at my company one } \\
\text { year from today? }\end{array}$ & $\begin{array}{l}\text { Hair et } \\
\text { al.(2010) }\end{array}$ \\
\hline
\end{tabular}


Literature review shows that there is not only a dearth of studies related to the impact of knowledge management and its impact on people, but there is an absence of empirical research that examined the role of internalization and externalization sub-processes of knowledge capture and socialization as well as exchange sub-processes of knowledge sharing on employee learning, adaptability, job satisfaction, and intention to stay in an organization in the context of Bangladesh. Knowledge of employees in an organization is the base that ensures core competencies that help improve the efficiency of the employees and reduce the overall costs of the organization (Davenport \& Prusak, 1998). Employees with inadequate knowledge of the organization's products will increase the overall costs of the organization (Benton, 2014). So, Knowledge management through externalization and internalization can enhance employee learning. Based on this, this study hypothesizes that:

H1a: Internalization leads to employee learning.

H1b: Externalization leads to employee learning.

Learning allows employees to grow continuously and change in response to the market and the technology and by doing so; it causes employees to be more flexible. Once the quest for learning new things among employees is instilled and they start adapting based on the new knowledge, it will enable effective organizational performance by making it possible for people to handle situations in ways that are in the organization's best interest. So, understanding the knowledge, competence, expertise, as well as skills help an employee to adapt to the new knowledge (Becerra-Fernandez et al., 2004). Employees are likely to adapt, accept change, and prepare to respond to changes when they interact with each other. So, KM efforts are intended to continually expose employees to new ideas and making employees ready for changes as they are in touch with the latest ideas and development. Increased employee adaptability can make an organization as a fast-changing organization. Thus, this study hypothesizes that:

H2a: Internalization facilitates employee adaptability.

H2b: Externalization facilitates employee adaptability.

Sharing tacit knowledge such as insights, intuitions, and hunches in the form of cognitive and technical elements and explicit knowledge that is expressed into words, numbers, symbols, and diagrams in symbolic form or/and natural language can improve employee learning. The process of active learning by way of sharing information and knowledge among organizational members, enables individuals and organizations to reflect on the consequences of their behaviors and actions, to obtain insights from an environment where they operate, to understand the situation, and hence to interpret the meaning and react to it in more accurate approaches (Jones et al., 2003). Thus, this study hypothesizes that:

H3a: Socialization facilitates employee learning.

H3b: Exchange facilitates employee learning.

As it has been stated earlier knowledge sharing supports the process through which explicit or implicit knowledge is communicated to other individuals through socialization and exchange subprocesses. Knowledge sharing enables managers to keep the individual learning flowing throughout the company and integrate it for practical applications. Besides, people within an organization, by way of sharing their thoughts, beliefs, knowledge, and experience, mutually establish their common understandings. These practical applications and common perceptions are organizational knowledge. This results not only in the enhancement of employees' capabilities but also the contribution to overall organizational effectiveness and bottom-line profit (Yang, 2007). Sharing knowledge can continually expose employees to new ideas and ideas and developments can make employees ready for the change. Therefore, improvement in skills and employees' adaptability of new knowledge and skills can increase their market value as well as can make an organization as a fast-changing organization. This study thus hypothesizes that:

H4a: Socialization facilitates employee adaptability.

H4b: Exchange facilitates employee adaptability. 
Employee learning is defined by Cheung (2011) as the activities that an employee engages in acquiring new knowledge and skills within his or her current job. Job satisfaction, on the other hand, is the level of contentment employees feel about their work, which can affect performance. This feeling of job satisfaction is mainly based on an individual's perception of satisfaction (Anon., 2015). For any organization to flourish, it must be able to improve employees' job satisfaction. When KM processes encourage the employee to learn from each other, they are likely to possess the knowledge needed to adapt whenever organizational circumstances require. Being better prepared for change and more knowledgeable, employee job satisfaction is impacted, thereby reducing the turnover rate. Although it is sometimes difficult to quantify an employee's job satisfaction, this study hypothesizes that:

H5: Employee learning increases job satisfaction

Cullen et al. (2014) defined adaptability as an individual's ability, skill, disposition, willingness, and motivation, to change or fit the different task, social, and environmental features. Cullen et al. (2014) argued that individual differences in adaptability predict the extent to which employees perceive organizational support for at least two reasons: i) adaptable employees are proactive in their approach and take responsibility for adjusting to the situation which includes learning the skills necessary to function efficiently, and ii) adaptable individuals are more likely to perceive situations in a positive light and are more sensitive to environmental cues, which increases their ability to notice and appreciate even small supportive actions by their organizations. According to Murray (1999) as cited by Suliman and Al-Hosani (2014), researchers have attempted to correlate job satisfaction with performance, turnover, and absenteeism but the relationship between Employee adaptability and job satisfaction in the knowledge management context have not been heavily discussed in the literature. With this in mind, this study hypothesizes that:

H6: Employee adaptability facilitates job satisfaction.

Job satisfaction refers to the pleasurable or positive emotional state resulting from the appraisal of one's job or job experiences (Bang, 2015). The organizational behavior literature is replete with both theoretical and empirical evidence that organizational commitment fully or partially mediates the relationship between job satisfaction and turnover intention (Preez and Bendixen, 2015). Turnover intention is defined as the intention of an organizational member, and if individuals are not satisfied with their jobs, they are less likely to stay with the organizations, which eventually causes a turnover (Bang, 2015). The opposite of turn over intention is the intention to stay that refers to the extent to which an employee intends to continue working for an organization and is not participating in activities that make quitting more likely (Hair et al., 2010). Thus, this study hypothesizes that:

H7: Job satisfaction leads to Intention to stay.

ANALYSIS STRATEGY AND DISCUSSION

\subsection{Sample Description}

A survey has been developed to explore those research question elucidated above. All measures, including the performance measure, are based on respondents' perception. A questionnaire developed in this regard was primarily composed of the following dimensions: internalization, externalization, socialization, exchange, learning, adaptability, job satisfaction and intention to stay. Reliability and validity tests have been conducted for each construct with measures. Cronbach Alpha $(\alpha)$ reliability estimates have been used to measure internal consistency. To ensure that the instrument has reasonable construct validity, both exploratory and confirmatory factor analyses have also been used.

The sample for this study consisted of 254 respondents from 23 different branches of eight commercial banks namely: Mutual Trust bank, BASIC Bank, Arab Bangladesh Bank, Dutch Bangla Bank, Shahjalal Islami Bank, United Commercial bank Limited, Premier bank and Meghna Bank in Bangladesh. For the survey, the respondents indicated their agreement or disagreement with the statement concerning each construct. A 5-point Likert scale was used. Every organization under study has over 100 
employees. The respondents were from many different departments, including Finance, Customer Service, Information Systems, Human Resources, and Administration, etc. Out of 300 questionnaires, 254 were returned, and this represented $84.66 \%$ of returned surveys.

\subsection{Analysis and Results}

This study used SmartPLS. The PLS algorithm using SmartPLS was run four times to drop items that loaded poorly. All together fifteen items were dropped in 4 iterations until the loadings of all the remaining items on their intended constructs were found to be 0.7 or higher. The internal consistency of each construct was assessed using composite reliability and Cronbach alpha. The average variance extracted (AVE) was calculated for each latent construct; and all constructs exceeded Chin's (1988) guideline of 0.5 , meaning at least $50 \%$ of the variance in indicators was accounted for by its construct (as cited in Bateman et al. 2011).

\subsection{Demographic Data}

The demographic characteristics of the sample included age, education, gender, rank, number of promotions, years of service, and the organizational unit as shown in table 2.

Table 2: Demographic Characteristics $(\mathbf{N}=\mathbf{2 5 4})$

\begin{tabular}{||l|l|l||}
\hline Gender & Age & Education \\
\hline Male: $190(74.8 \%)$ & $<=30$ Years: $52(20.5 \%)$ & Graduate: $254(100.0 \%)$ \\
\hline Female: $64(25.2 \%)$ & $31-40$ Years: $169(66.5 \%)$ & \\
\hline & $41-50$ Years: $29(11.4 \%)$ & \\
\hline Job Rank & $>50$ Years: $4(1.6 \%)$ & \\
\hline Senior Management: $8(3.2 \%)$ & Years of Service & Business Unit \\
\hline $\begin{array}{l}\text { Middle Management: } 126 \\
(49.6 \%)\end{array}$ & 0 - 1 Year: $44(17.3 \%)$ & Information System: $6(2.3 \%)$ \\
\hline Technical Staff: $31(12.2 \%)$ & $4-6$ Years: $57(22.5 \%)$ & Finance: $111(43.7 \%)$ \\
\hline Support Staff: $89(35.0 \%)$ & $>=7$ Years: $54(21.2 \%)$ & Customer Service: $66(26.0 \%)$ \\
\hline & & Administration: $17(6.7 \%)$ \\
\hline & & Others: $47(18.5 \%)$ \\
\hline
\end{tabular}

In this study among the respondents, the majority were male $75 \%$ and female $25 \%$. As far as the distribution of age among respondents are concerned, the majority of the respondents $(66.5 \%)$ were in the age group of 31 to 40 years old. 20.5 percent of the respondents were 30 years or below, 11.5 percent in the age group of 41-50 years old and 1.5 percent respondents were above 50 years old. It may also be mentioned here that all the respondents in this study have a Graduate Degree. As for job ranking, the majority of the respondents in this study were middle management staff $(49.5 \%)$. The second largest were support staff $(35 \%)$ followed by technical staff $(12.5 \%)$ and senior management staff $(3 \%)$. When asked about the years of service in their respective organization, 39 percent respondents have been with their organization for 2 to 3 years, followed by $22.5 \%$ for 4 to 6 years $21 \%$ for over seven years and $17.5 \%$ of the respondents have been with their respective organization for one year or less. When it comes to respondents' business unit, the majority of the surveyed respondents were from Finance (44\%), followed by Customer service (26\%), Others (18\%), Administration (7\%), HRM $(3 \%)$ and Information system (2\%). 


\subsection{Measurement Model}

A measurement theory specifies how measured variables logically and systematically represent constructs involved in a theoretical model. In other words, measurement theory determines a series of relationships that suggest how measured variables represent a latent construct that is not measured directly ( (Hair et al., 2010). The PLS factorial validity of the measurement model deals with whether the pattern of loadings of the measurement items corresponds to the theoretically anticipated factors (Gefen and Straub, 2005). Using Chin's (1998) approach, as cited in Bateman et al. (2011), this study tested the adequacy of the measurement model using three standard tests of convergent validity. First, the PLS algorithm was run four times to drop items that loaded poorly. After the first run, seven items were dropped due to poor loadings (EL5, EX6, EXT6, INTL1, IS2, SOC5, SOC6). After the second run, three items were dropped due to poor loadings (EL4, EXT4, JS3) and after the third run, five items were found to have loaded poorly (EA5, EX3, EXT3, EXT5, INTL 3). All together fifteen items were dropped in four iterations until the loadings of all the remaining items on their intended constructs were found to be 0.7 or greater. Table 3 shows indicators are loaded high on their respective constructs and low on other constructs and shows no presence of cross-loadings.

Second, the internal consistency of each construct was assessed using composite reliability and Cronbach alpha. Third, the average variance extracted (AVE) was calculated for each latent construct; and all constructs exceeded Chin's (1988) guideline of 0.5 , meaning at least $50 \%$ of the variance in indicators was accounted for by its respective construct (as cited in Bateman et al. 2011). 
Table 3: Factor Loadings

\begin{tabular}{||r|r|r|r|r|r|r|r|r||}
\hline & EA & EL & EX & EXT & INTL & & JS & SOC \\
\hline EA1 & $\mathbf{0 . 8 1 4 2}$ & 0.294 & 0.2612 & 0.2292 & 0.2259 & 0.1212 & 0.3764 & 0.3195 \\
\hline EA2 & $\mathbf{0 . 7 9 7 3}$ & 0.2227 & 0.2789 & 0.2418 & 0.3308 & 0.1727 & 0.2521 & 0.3927 \\
\hline EA3 & $\mathbf{0 . 7 6 1 4}$ & 0.3116 & 0.3014 & 0.2644 & 0.3128 & 0.2111 & 0.3544 & 0.3998 \\
\hline EA4 & $\mathbf{0 . 8 4 3 3}$ & 0.3515 & 0.3394 & 0.2343 & 0.3834 & 0.1729 & 0.4772 & 0.4781 \\
\hline EL1 & 0.268 & $\mathbf{0 . 7 8 0 9}$ & 0.4882 & 0.405 & 0.2073 & 0.3124 & 0.4301 & 0.3132 \\
\hline EL2 & 0.2939 & $\mathbf{0 . 8 4 9 2}$ & 0.5638 & 0.5419 & 0.327 & 0.2098 & 0.3609 & 0.3484 \\
\hline EL3 & 0.3507 & $\mathbf{0 . 8 3 0 8}$ & 0.5258 & 0.5187 & 0.3288 & 0.1958 & 0.4948 & 0.3943 \\
\hline EX1 & 0.2717 & 0.4134 & $\mathbf{0 . 6 9 5 7}$ & 0.4139 & 0.2755 & 0.2996 & 0.3342 & 0.2747 \\
\hline EX2 & 0.388 & 0.386 & $\mathbf{0 . 7 4 3 6}$ & 0.2923 & 0.3617 & 0.1617 & 0.2996 & 0.4204 \\
\hline EX4 & 0.1583 & 0.5806 & $\mathbf{0 . 7 6 7 6}$ & 0.4471 & 0.2961 & 0.2982 & 0.4375 & 0.314 \\
\hline EX5 & 0.3103 & 0.5358 & $\mathbf{0 . 8 0 3 5}$ & 0.3984 & 0.4297 & 0.2684 & 0.4608 & 0.3617 \\
\hline EXT1 & 0.1972 & 0.498 & 0.41 & $\mathbf{0 . 8 5 0 1}$ & 0.2499 & 0.2985 & 0.311 & 0.3032 \\
\hline EXT2 & 0.3182 & 0.544 & 0.4846 & $\mathbf{0 . 8 9 4 7}$ & 0.2649 & 0.305 & 0.422 & 0.3055 \\
\hline INTL2 & 0.2975 & 0.2802 & 0.2958 & 0.2387 & $\mathbf{0 . 7 5 5 8}$ & 0.0667 & 0.1909 & 0.4011 \\
\hline INTL4 & 0.275 & 0.256 & 0.3264 & 0.2176 & $\mathbf{0 . 7 7 1 8}$ & 0.2576 & 0.2195 & 0.3477 \\
\hline INTL5 & 0.3395 & 0.2825 & 0.4265 & 0.2275 & $\mathbf{0 . 7 9 0 8}$ & 0.2031 & 0.2951 & 0.4565 \\
\hline IS1 & 0.1466 & 0.1538 & 0.2335 & 0.2243 & 0.1577 & $\mathbf{0 . 7 4 6 9}$ & 0.2541 & 0.1833 \\
\hline IS3 & 0.1414 & 0.298 & 0.3212 & 0.3629 & 0.1349 & $\mathbf{0 . 8 5 4 7}$ & 0.3463 & 0.1436 \\
\hline IS4 & 0.2233 & 0.2344 & 0.2723 & 0.2486 & 0.2517 & $\mathbf{0 . 8 3 8 3}$ & 0.3623 & 0.2421 \\
\hline JS1 & 0.2747 & 0.4151 & 0.3779 & 0.3464 & 0.1772 & 0.3609 & $\mathbf{0 . 7 9 4 6}$ & 0.2295 \\
\hline JS2 & 0.3755 & 0.4395 & 0.5138 & 0.3721 & 0.3035 & 0.3118 & $\mathbf{0 . 8 2 2 1}$ & 0.3283 \\
\hline JS4 & 0.4393 & 0.4002 & 0.3581 & 0.2889 & 0.2441 & 0.2856 & $\mathbf{0 . 7 9 6 1}$ & 0.3725 \\
\hline JS5 & 0.4268 & 0.459 & 0.4304 & 0.3803 & 0.2748 & 0.352 & $\mathbf{0 . 8 6 1}$ & 0.3391 \\
\hline SOC1 & 0.4038 & 0.3253 & 0.3923 & 0.2424 & 0.4258 & 0.1581 & 0.2594 & $\mathbf{0 . 8 1 1 7}$ \\
\hline SOC2 & 0.4844 & 0.3302 & 0.3404 & 0.2907 & 0.3524 & 0.1797 & 0.3373 & $\mathbf{0 . 8 4 7 2}$ \\
\hline SOC3 & 0.387 & 0.3922 & 0.3933 & 0.2653 & 0.4791 & 0.176 & 0.3069 & $\mathbf{0 . 8 3 5 6}$ \\
\hline SOC4 & 0.3443 & 0.3543 & 0.3552 & 0.3373 & 0.4524 & 0.2495 & 0.3617 & $\mathbf{0 . 7 4 9 8}$ \\
\hline
\end{tabular}

Table 4: Bolded values are the SQRT of AVE for each latent construct.

\begin{tabular}{||l|c|c|c|c|c|c|c|c||}
\hline & EA & EL & EX & EXT & INTL & IS & JS & SOC \\
\hline EA & $\mathbf{0 . 8 0 5}$ & 0 & 0 & 0 & 0 & 0 & 0 & 0 \\
\hline EL & 0.373 & $\mathbf{0 . 8 2 1}$ & 0 & 0 & 0 & 0 & 0 & 0 \\
\hline EX & 0.371 & 0.641 & $\mathbf{0 . 7 5 4}$ & 0 & 0 & 0 & 0 & 0 \\
\hline EXT & 0.301 & 0.599 & 0.516 & $\mathbf{0 . 8 7 3}$ & 0 & 0 & 0 & 0 \\
\hline INTL & 0.395 & 0.354 & 0.456 & 0.295 & $\mathbf{0 . 7 7 3}$ & 0 & 0 & 0 \\
\hline IS & 0.212 & 0.288 & 0.341 & 0.346 & 0.225 & $\mathbf{0 . 8 1 5}$ & 0 & 0 \\
\hline JS & 0.465 & 0.524 & 0.514 & 0.424 & 0.307 & 0.400 & $\mathbf{0 . 8 1 9}$ & 0 \\
\hline SOC & 0.501 & 0.431 & 0.455 & 0.348 & 0.523 & 0.233 & 0.389 & $\mathbf{0 . 8 1 2}$ \\
\hline
\end{tabular}


As a rule of thumb, the square root of the AVE of each construct should be much larger than the correlation of the specific construct with any of the other constructs in the model (Grefen and Straub, 2005). The results of the square root of AVE on the PLS algorithm (Table 4) for each construct was found to be above 0.75 and larger than the correlation of that construct with other constructs. Therefore, it can safely be concluded that, in the case of these data, all the square roots are much larger than any correlation, which shows a necessary aspect of the discriminant validity of the latent constructs.

Table 5: t-values

\begin{tabular}{||c|r|r||}
\hline $\begin{array}{l}\text { Indicators- } \\
\text { construct }\end{array}$ & Correlations & T statistics \\
\hline EA1 <- EA & 0.8142 & 31.5 \\
\hline EA2 <- EA & 0.7973 & 23.5682 \\
\hline EA3 <- EA & 0.7614 & 24.4346 \\
\hline EA4 <- EA & 0.8433 & 46.5318 \\
\hline EL1 <- EL & 0.7809 & 23.0625 \\
\hline EL2 <- EL & 0.8492 & 35.6904 \\
\hline EL3 <- EL & 0.8308 & 24.5293 \\
\hline EX1 <- EX & 0.6957 & 14.0851 \\
\hline EX2 <- EX & 0.7436 & 20.4167 \\
\hline EX4 <- EX & 0.7676 & 19.6644 \\
\hline EX5 <- EX & 0.8035 & 31.3776 \\
\hline $\begin{array}{l}\text { EXT1 <- } \\
\text { EXT }\end{array}$ & 0.8501 & 30.2519 \\
\hline $\begin{array}{l}\text { EXT2 <- } \\
\text { EXT }\end{array}$ & 0.8947 & 43.0608 \\
\hline $\begin{array}{l}\text { INTL2 <- } \\
\text { INTL }\end{array}$ & 0.7558 & 22.0976 \\
\hline $\begin{array}{l}\text { INTL4 <- } \\
\text { INTL }\end{array}$ & 0.7718 & 16.7892 \\
\hline $\begin{array}{l}\text { INTL5 <- } \\
\text { INTL }\end{array}$ & 0.7908 & 21.421 \\
\hline IS1 <- IS & 0.7469 & 15.7208 \\
\hline IS3 <- IS & 0.8547 & 29.943 \\
\hline IS4 <- IS & 0.8383 & 35.9956 \\
\hline JS1 <- JS & 0.7946 & 27.0567 \\
\hline JS2 <- JS & 0.8221 & 33.7493 \\
\hline JS4 <- JS & 0.7961 & 24.8109 \\
\hline JS5 <- JS & 0.861 & 38.293 \\
\hline $\begin{array}{l}\text { SOC1 <- } \\
\text { SOC }\end{array}$ & 0.8117 & 31.9059 \\
\hline $\begin{array}{l}\text { SOC2 <- } \\
\text { SOC }\end{array}$ & \\
\hline $\begin{array}{l}\text { SOC3 <- } \\
\text { SOC }\end{array}$ & 0.8472 & 40.3135 \\
\hline $\begin{array}{l}\text { SOC4 <- } \\
\text { SOC }\end{array}$ & & 35.3272 \\
\hline \hline
\end{tabular}


Convergent validity is shown when each measurement item loads with a significant t-value on its latent construct and correlates strongly with its assumed theoretical construct. Typically, the p-value of the tvalue should be significant at least at the 0.05 alpha protection levels (Gefen and Straub, 2005). At the 95\% confidence level or the 0.05 significance level, the t-value must be greater than 1.96 for each of the loadings of the corresponding constructs. So, convergent validity is shown when the $t$-values of the outer model loadings are above 1.96. The t-values of the loadings are, in essence, equivalent to t-values in the least-squares regression (Grefen and Straub, 2005). The above bootstrap report in Table 5 shows that for every measurement item in this study, the corresponding t-statistic is considerably greater than 1.96. Table 5, therefore, shows evidence of convergent validity in the measurement model.

\section{Table 6: Descriptive Statistics}

\begin{tabular}{||l|c|c|c|c|c|c|c|c||}
\hline & EA & EL & EX & EXT & INTL & IS & JS & SOC \\
\hline AVE & 0.65 & 0.67 & 0.57 & 0.76 & 0.60 & 0.66 & 0.67 & 0.66 \\
\hline $\begin{array}{l}\text { Composite } \\
\text { Reliability }\end{array}$ & 0.88 & 0.86 & 0.84 & 0.86 & 0.82 & 0.86 & 0.89 & 0.89 \\
\hline Cronbach's Alpha & 0.82 & 0.76 & 0.75 & 0.69 & 0.66 & 0.75 & 0.84 & 0.83 \\
\hline
\end{tabular}

Two estimates of reliability are the Cronbach's alpha and the composite reliability shown in Table 6. The generally agreed upon lower limit for Cronbach's alpha is 0.70 , although it may decrease to 0.60 in exploratory research (Hair et al., 2010). In analyzing the current study, Table 6 shows the lower limit of Cronbach's alpha is 0.66 , and the composite reliability is 0.817 for each latent construct an upper limit of Cronbach's alpha is 0.83 and composite reliability 0.89 which indicate the reliability of the measurement model. High construct reliability means that internal consistency exists (Hair et al., 2010).

\subsection{Hypotheses Test}

The results of the PLS model are explained in Figure 2. The model indicates significant $(\mathrm{p}<0.05)$, and non-significant path coefficients and the variance explained in the predicted constructs. Constructs included in the model determines each endogenous construct, and so each one is seen as an outcome based on the hypothesis listed above. It is noted here that EL (Employee learning), EA (Employee adaptability), and JS (Job satisfaction) are listed as outcomes in some hypotheses and as predictors in others. As for hypotheses 1 (the effect of internalization and externalization on employee learning), the results indicate that externalization (EXT) positively affect employee learning (EL) in an organization $(\beta=0.345, \mathrm{p}<0.05)$ but not internalization (INTL). Thus hypothesis $1 \mathrm{~b}$ is supported but not 1 a. For hypotheses 2 , when it comes to employee adaptability (EA), the findings of this study show that internalization (INT) positively affect employee adaptability $(\beta=0.139, \mathrm{p}<0.05)$ but not externalization (EXT). Thus hypothesis $2 \mathrm{a}$ is supported but not $2 \mathrm{~b}$. As for hypotheses 3, both socialization (SOC) and exchange (EX) significantly affect employee learning ( $\beta=0.125,0.406$ $\mathrm{p}<0.05)$. Thus hypotheses $3 \mathrm{a}$ and $3 \mathrm{~b}$ are supported. As for knowledge sharing $(\mathrm{SOC})$ and employee adaptability (EA) only socialization (SOC) turns out to significantly affect employee adaptability(EA) ( $\beta$ $=0.352, \mathrm{p}<0.05)$ but not exchange $(\mathrm{EX})$. Thus hypothesis $4 \mathrm{a}$ is supported but not $4 \mathrm{~b}$. This study also finds that willingness to learning (EL) positively affect employees' job satisfaction(JS) $(\beta=0.407$, $\mathrm{p}<0.05)$. So hypothesis 5 is also supported. In addition to employee learning, this study also finds a significant relationship between employee adaptability and job satisfaction $((\beta=0.313, \mathrm{p}<0.05)$ as well as job satisfaction and intention to stay $((\beta=0.400, \mathrm{p}<0.05)$. Thus both the hypotheses 6 and 7 are supported. 
Figure 2: Path Coefficients (Number within the parentheses represent $\mathbf{R}^{2}$ )

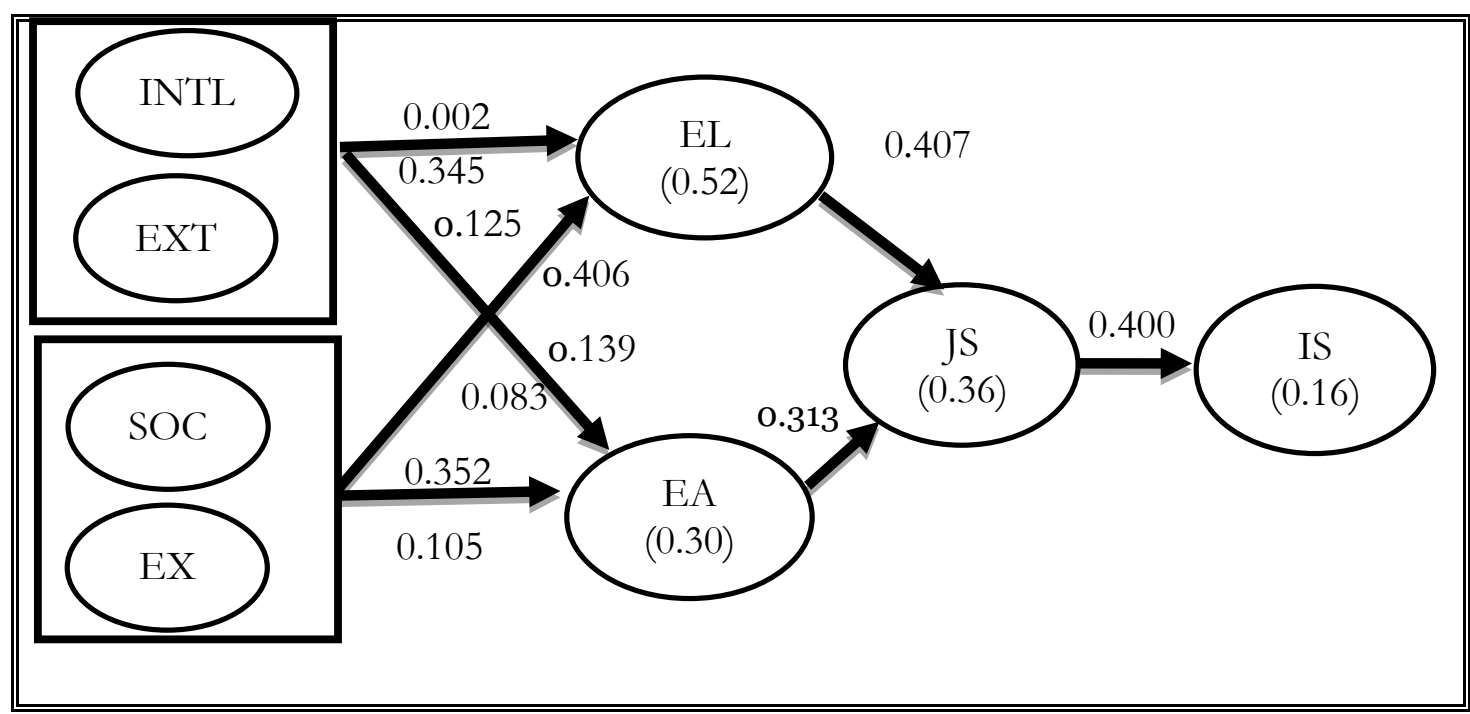

The result of the measurement and structural model test lend support for the proposed research model. All the paths, except three, in the model, appear to be statistically significant. In this study, two research questions that have been delineated above, have been tested using eleven hypotheses. Since eleven hypotheses have been derived from two research questions and three are found to be not significant, there is no way to conclude that research questions 1 and 2 are both significant. As far as the impact of internalization and externalization sub-processes of knowledge capture on employee learning is concerned, the only externalization has been found to lead to employee learning significantly. As it has been explained above, externalization is the process when tacit knowledge is converted into explicit knowledge. Externalization is the key to knowledge creation as it creates new explicit knowledge from tacit knowledge (Nonaka et al., 2001). Conversion of tacit knowledge into explicit knowledge can be influenced by dialogue and mutual reflection, and the effectiveness of externalization can be reinforced by learning and motivation (Nonaka and Takeuchi, 1995). Employees engage in learning activities and develop the knowledge base for the cognitive systems and shared memories, which lead to organizational learning. The positive impact of externalization on employees learning may cause employees to focus on learning for their job, resulting in a knowledge base that focuses on a relatively narrow domain of interest (i.e., one's job) and also outside their current job, resulting in a knowledge base that broadly covers several areas of interest (Cheung, 2011). The significant relationship of externalization and employee learning may develop a learning culture within the organization that can encourage collaboration and team learning and establishes systems to capture knowledge for the more significant benefit of the organization.

As for employee adaptability, in this study, the only internalization of knowledge capture process of knowledge management has been found to have a significant relationship with employee adaptability. Adaptability as defined by Ployhart and Bliese (2006) as an individual's ability, skill, disposition, willingness, and motivation, to change or fit the different task, social, and environmental features (as cited in Cullen et al., 2014). Adaptable individuals take responsibility for adjusting to the situation. In the case of using new technology, this would include learning the skills necessary to operate the equipment efficiently. The proactive, resourceful, and resilient nature of adaptable employees allows them to acquire these skills on their own and also to seek out and use support from their organization (Cullen et al., 2014). Knowledge internalization as mentioned above is the process of embodying explicit knowledge into tacit knowledge, and it is through internalization; explicit knowledge created is 
shared throughout an organization and converted into tacit knowledge by individuals (Tsai and Lee, 2006). Sabherwal and Becerra-Fernandez (2003) found in their study that both the internalization and externalization processes of knowledge capture mainly focus at the individual level, internalization is intrinsically related to learning, and externalization is essential to articulation. However, this study finds that in the context of the banking industry in Bangladesh, while externalization leads employees to enhanced learning, internalization, on the other hand, helps employees to be more adaptable. The above findings could be related to the specific nature of the banking industry. The qualitative interviews indicated that the banking industry under the survey emphasizes the conversion of tacit knowledge to explicit knowledge for employee learning and the conversation of explicit knowledge to tacit knowledge for employee adaptability. This finding is surprising because internalization, as explained by Sabherwal and Becerra-Fernandez (2003), is intrinsically related to learning and externalization is essential to knowledge articulation, which can help facilitate employee adaptability.

As for the two sub-processes of knowledge sharing: socialization and exchange have been found to be significantly related to employee learning in an organization. While internalization and externalization both focus mainly at the individual level - socialization and exchange focus at the individual, group, or organizational levels (Sabherwal and Becerra-Fernandez, 2003 and Becerra-Fernandez et al., 2004). Knowledge sharing through socialization and exchange occurs when an individual is willing to assist as well as to learn from others in the development of new competencies. As mentioned by Bornemann and Sammer (2003) knowledge could increase its value when it is shared with and transferred to others (cited in Yang, 2007). The process of learning by way of sharing information and knowledge among the employees in an organization may enable individuals and organizations to reflect on the consequences of their behaviors and actions, to obtain insights from an environment where they operate, to understand the environment, and hence to interpret the meaning and react to it in more accurate approaches (Jones et al., 2003 cites in Yang, 2007). As the organization provides opportunities for its members to share their experiences and new learning and perspectives with others, individuals learning should stimulate organizational learning (Yang, 2007).

As for knowledge sharing and employee adaptability, only socialization sub-processes of the knowledge sharing process turns out to be significantly related to employee adaptability in the case of the banking industry under study. That means tacit knowledge shared between employees enable employees to be more adaptable. This is consistent with hypothesis H2a that was also found to significant in this study. Internalization, which is the conversion of tacit knowledge from explicit knowledge, is significantly related to employees' adaptability and socialization, which is sharing of tacit knowledge, is found to be significantly related to employees' adaptability in the banking industry of Bangladesh under study.

With regard to the employees' willingness to learn and employees' job satisfaction, this study finds the relationship between willingness to learn and job satisfaction are significantly related to each other. Employees' willingness to learn may provide employees domain-specific knowledge skills and may be used for the production of novel ideas with the potential utility to the particular domain of interest (Cheung, 2011). These domain-specific knowledge skills of employees increase the level of contentment that employees feel about their work. In addition to employee learning, this study also finds a significant relationship between employee adaptability and job satisfaction. This study also supports the relationship between job satisfaction and employees' intention to stay. Employee turnover as mentioned by Abelson and Baysiner (1994), Dalton et al., (1981) may at times benefit firms by reducing stagnation, improving innovation, eliminating poor performers and reducing costs (cited in Droege and Hoobler, 2003). The potential disadvantage of employee turnover as also mentioned by Droege and Hoobler (2003) is the loss of organizational level tacit knowledge, and as a result, employee turnover is considered a major obstacle for many organizations. A similar study conducted by Bang (2015) among some nonprofit sports organizations' volunteers found that job satisfaction among volunteer predicted intention to stay with their organizations.

\subsection{Theoretical Implications}

The results of this study have important theoretical implications that impact academics within the KM community. The findings of this study contribute to further the understanding of how knowledge 
management initiatives should be implemented in organizations especially financial organizations. From a theoretical perspective, the results confirmed that knowledge capture and knowledge sharing play a significant explanatory role in how employee learning and adaptability influence employees' job satisfaction and intention to stay. The current study contributes theoretically to the existing literature of knowledge management that how knowledge capture and knowledge sharing motivate employees to learn and adapt and how learning and adaptability contribute to job satisfaction and staying intention. The results also revealed that knowledge management initiatives shape the employees' quest for knowledge and adaptability. The results of this research also confirm that for the financial service firms studied, knowledge management plays an important role in employees' job satisfaction and intention to stay in the job. A successful knowledge capture and knowledge sharing processes would result in employees interacting and serving customers better. The results of this study show that not all the subprocesses will have equal impact on employees.

\subsection{Practical Implications}

The findings of this study suggest that to have a positive impact on employees, the focus of an organization should not be specific knowledge management processes, instead focus should be subprocesses of specific knowledge management processes.

A major takeaway for practitioners especially the management or managers from this study is that employees may be nurtured to create, capture, and share the type of knowledge desired by the organization. Managers can establish platforms for employees within the same functional area and across different functional units to engage in knowledge and experience sharing. This study also suggests that employees' learning and adaptability depend on the usability and comfortability of the knowledge management initiatives undertaken by the management. Practitioners may also employ the same experimental method using the instruments developed for this study to analyze the impact of internalization and externalization of knowledge capture and socialization as well as the exchange of knowledge sharing on employee learning, adaptability, job satisfaction and finally employees' intention to stay in the job. Practitioners may also employ the same experimental method using the instruments developed for this study as the knowledge management assessment instrument developed in this study have passed the tests of reliability and validity.

\section{$4 \quad$ LIMITATIONS}

As with any empirical study, this study has some limitations. First, the sample in this study can be considered as purposive sampling. This study involved self-administrated questionnaires and was open to all levels of staff. The second limitation of this study is the sample size. The sample size in some of the eight commercial banks from 23 different branches was small and might not be representative of all the players who might be instrumental in the effective utilization of knowledge management initiatives. Third, it can be safely stated that, since the hypotheses were tested only with a sample from the financial institutions in Bangladesh, it may not be appropriate to generalize the results to other cultures and countries.

\section{DIRECTIONS FOR FUTURE RESEARCH}

This study mainly focused on only two processes of knowledge management. The empirical model that was presented and studied in this research opens up multiple opportunities for future research. The model examined knowledge capture and knowledge sharing from banks' employees' perspectives and used that as an indication of the success of a knowledge management initiative. This study has demonstrated a strong positive relationship between knowledge capture, knowledge sharing, and job satisfaction, and intention to stay via learning and adaptability. It is recommended that future research should explore other two process of knowledge management or all the processes of knowledge management at a much more granular level as elucidated by Becerra-Fernandez et al. 2003 and the 
impact on four endogenous variables that were studied in this paper. Researchers could also explore the effects of other variables such as organizational climate, leadership behaviors, and organizational commitment on knowledge sharing and knowledge capture and how knowledge sharing and knowledge capture impact employee learning, adaptability, job satisfaction and intention to stay. In addition, future research could take larger sample sizes from all different management levels across various industries. More conclusive results are needed to see which knowledge management impacts and supports job satisfaction and intention to stay in different industries. This will further help us understand how knowledge workers improve their learning and adaptability using different knowledge management processes across diverse business industries.

Researchers in future research should also look at a more detailed approach of knowledge capture and knowledge sharing processes. As mentioned by Kulkarni et al. (2006-7) those KM processes should be treated at a much more granular level by addressing the nature of identification and vetting processes, and by analyzing workflow steps that facilitate capture and sharing of identified knowledge as separate constructs to understand the antecedents of KM success.

Another area where future research might be conducted is how the usage of IT artifacts can help improve employees' learning and adaptability - thereby job satisfaction and intention to stay. Future research should investigate IT artifacts in terms of system quality, information quality, and service quality and user satisfaction and how they impact knowledge management processes.

Knowledge capture and knowledge sharing lie at the core of knowledge management, and it reflects employees' willingness to learn and share their valuable knowledge as well as their actions facilitating the exchange of relevant information with other members across the organization (Trivellas et al., 2015). Building on the shared values, norms, accepted practices or perceptions held by employees within an organization, knowledge capture and knowledge sharing are evolved and treated as a knowledge-centered culture which molds individual behavior (Trivellas et al., 2015). The findings of this study clearly show that knowledge capture and knowledge sharing are the precursor of employee learning, adaptability, job satisfaction and intention to stay. To understand the financial institutions' employees' perceptions and how knowledge capture and sharing help enhance learning and adaptability and thereby job satisfaction and intention to stay on the job, this study resulted in several theoretical and practical contributions that will help guide management or organizations to select and implement the appropriate knowledge management processes. There is a need for management or organizations to adopt knowledge capture and sharing techniques, practices, and nurture knowledge management culture through proper mechanisms and technologies to improve employees learning quest and adaptability. To remain competitive in a very competitive world, knowledgeable and adaptable employees are essential resources. As $\mathrm{KM}$ evolves and new factors are introduced, knowledge (both the tacit and explicit) must be captured through internalization and externalization and shared through socialization and exchange. Since organizations need to become smarter and faster, intellectual capital is the means for transferring the knowledge to knowledge workers. The information is captured and transferred so that relevant data are transmitted from one individual to another (Misuraca, 2013). As organizations shift toward a dynamic workforce that applies knowledge management mechanisms to foster learning and adaptability among employees in the organization, it becomes crucial that these organizations understand the impact of knowledge capture and knowledge sharing on job satisfaction and intention to stay. 


\section{REFERENCES}

Abelson, M., \& Baysinger, B. (1984). Optimal and Dysfunctional Turnover: Toward an organizational level model. Academy of Management Review, 9, 331-341.

Bang, H. (2015). Volunteer age, job satisfaction, and intention to stay. Leadership and Organization Development Journal, 36(2), 162-176.

Bateman, P. J., Gray, P. H., \& Butler, B. S. (2011, December). The Impact of Community Commitment on Participation in Online Communities. Information Systems Research, 22(4), 841-854.

Becerra-Fernandez, I., Gonzalez, A., \& Sabherwal, R. (2004). Knowledge Management and KM Software Package. London, UK: Prentice Hall.

Benton, B. (2014, September 3). Importance of Employee Training. Retrieved from http://lineshapespace.com/importance-of-employee-training

Bornemann, M., \& Sammer, M. (2003). Assessment methodology to prioritize knowledge management related activities to support organizational excellence. Measuring Business Excellence, 7(2), 21-28.

Boumarafi, B., \& Jabnoun, N. (2008). Knowledge management and performance in UAE business organziations. Knowledge Management Research and Practice, 6, 233-238.

Boundless. Defining Job Satisfaction. (2015, July 21). Retrieved April 3, 2016, from https://www.boundless.com/management/textbooks/boundless-managementtextbook/organizational-behavior-5/drivers-of-behavior-44/defining-job-satisfaction-231$7247 /$

Cheung, S. Y. (2011). Refinement or breakthrough? The link between goal orientation , employee learning, creativity and job performance. ProQuest Dissertations Publishing.

Chin, W. (1998). The Partial least squares approach for structural equation modeling. In G. Marcoulides, Modern Methods for Business Research. (pp. 295-336). Mahwah, NJ: Lawrence Erlbaum Associates.

Cullen, K. L., Edwards, B. D., Casper, W. C., \& Gue, K. R. (2014). Employees' Adaptability and Perceptions of Change-Related Uncertainty: Implications for Perceived Organizational Support, Job Satisfaction, and Performance. Journal of Business Psychology, 269-280. doi:10.1007/s10869013-9312-y

Dalton, D., Krackhardt, D., \& Porter, L. (1981). Functional turnover: An emperical assessment. Journal of Applied Psychology, 66, 716-721.

Davenport, T., \& Prusak, L. (1998). Working Knowledge: How Organizations Manage What They Know. Cambridge: Harvard Business School Press.

Dibella, A., \& Nevis, E. (1998). How Organization Learn: An Integrated Strategy for Building Learning Capacity. San Francisco, CA: Jossey-Bass.

Droege, S. B., \& Hoobler, J. M. (2003). Employee turnover and tacit knolwedge diffusion: A network perspective. Journal of Managerial Issues, 15(1), 50-65.

Gefen, D., \& Straub, D. (2005). A Practicle Guide to Factorial Validity using PLS-Graph: Tutorial and Annotated Example. Communications of the Association for Information Systems, 16, 91-109.

Hair Jr., J. F., Black, W. C., Babin, B. J., \& Anderson, R. E. (2010). Multivariate Data Analysis. Upper Saddle River, NJ: Prentice Hall.

Ho, L.-A. (2008). What affects Organizational Performance? Industrial Management and Data Systems, 108(9), 1234-1254.

Hung, Y., Huang, S., Lin, Q., \& Tsai, M. (2005). Critical factors in adapting a knowledge management system for the pharmaceutical industry. Industrial Management and Data, 105(2), 164-183.

Jones, N., Herschel, R. T., \& Moesel, D. D. (2003). Using 'knowledge champions' to facilitate knowledge management. Journal of Knowledge Management, 7(1), 49-63.

Kianto, A., Vanhala, M., \& Heilmannn, P. (2016). The impact of knowledge management on job satisfaction. Journal of Knowledge Management, 4, 621-636.

King, W., Marks, P., \& McCoy, S. (2002). The most important issues in knowledge management: What can knowledge management do for corporate memory, management thinking and IS responsibilityas well as for overall business performance. Communication of the ACM, 45(9), 9397. 
Koh, S., Gunasekaran, A., Thomas, A., \& Arunachalam, S. (2005). The application of knowledge management in call centers. Journal of Knowledge Management, 9(4), 56-69.

Kulkarni, U. R., Ravindran, S., \& Freeze, R. (2006-7). A Knowledge Management Success Model: Theoritical Development and Emperical Validation. Journal of Management Information Systems, 23(3), 309-347.

Lee-Kelley, L., Blackman, D. A., \& Hurst, J. P. (2007). An exploration of the relationship between learning organisations and the retention of knowledge workers. The Learning Organization, 14(3), 204-221.

Lundvall, B., \& Nielson, P. (2007). Knowledge Management and Innovation Performance. International Journal of Manpower, 28, 207-223.

Mahnke, V., Pedersen, T., \& Venzin, M. (2005). The impact of knowledge management on MNC subsidiary performance: The role of absorptive capacity. Management International Review, 45(special issue), 101-119.

Marques, D. P., \& Simon, F. J. (2006). The Effect of Knowledge Management Practices on Firm Performance. Journal of Knowledge Management, 10(3), 143-156.

Misuraca, P. M. (2013, March). An examination of the relationship between job satisfaction and tacit knowledge sharing among knowledge workers: A quantitative study . Dissertation. UMI Dissertation Publishing.

Murray, R. (1999). Job satisfaction of professional and paraprofessional library staff at the University of North Carolina at Chapel hill. Dissertation .

Nonaka, I., \& Takeuchi, H. (1995). The knowledge-Creating Company: How Japanese Companies Create the Dynamics of Innovation. New York: Oxford University Press.

Nonaka, I., Toyama, R., \& Byosiere, P. (2001). A Theory of organizational knowledge creation: understanding the dynamic process of creating knowledge. In M. Dierkes, A. Antal-Berthoin, J. Child, \& I. Nonaka, Handbook of Organizational and learning Knowledge Creation (pp. 491-517). New York: Oxford University Press.

Ployhart, R., \& Bliese, P. D. (2006). Individual ADAPTability (IADAPT) theory: Conceptualizing the antecedents, consequences, and measurement of individual differences in adaptability. In S. Burke, L. Pierce, \& E. Salas (Eds.), Understanding adaptability: A prerequisite for effective performancewithin complex environments (pp. 3-39). St. Louis, MO: Elsevier Science.

Preez, R. D., \& Bendixen, M. T. (2015). The impact of internal brand management on employee job satisfaction, brand commitment and intention to stay. International Journal of Bank Marketing, 33(1), 78-91.

Sabherwal, R., \& Becerra-Fernandez, I. (2003). An Emperical Study of the Effect of Knowledge Management Processes at Individual, Group, and Organizational Levels. Decision Sciences, 34(2), 225-260.

Salazar, A., Hackney, R., \& Howells, J. (2003). The Strategic Impact of Internet Technology in Biotechnology and Pharmaceutical Firms: Insights from a Knowledge Management Perspective. Information Technology and Management, 4(2/3), 289-301.

Skyrme, D., \& Amidon, D. (1997). Creating the Knowledge-Based Business. London: Business Intelligence.

Singh, M., Shankar, R., \& Adish, K. (2006). Survey of Knowledge Management Practices in Indian Manufacturing Industries. Journal of Knowledge Management, 10(6), 110-128.

Suliman, A., \& Al-Hosani, A. A. (2014, February). Job satisfaction and knowlege sharing: The case of the UAE. Issues in Business Management and Economics, 2(2), 24-33.

Teh, P.-L., \& Sun, H. (2012). Knowledge sharing, job attitudes and organisational citizenship behaviour. Industrial Management and Data Systems, 112(1), 64-82.

Trivellas, P., Akrivouli, Z., Tsifora, E., \& Tsoutsa, P. (2015). The impact of knowledge sharing culture on job satisfaction in accounting firms. The mediating effect of general competencies. Procedia Economics and Finance, (pp. 238-247).

Tsai, M.-T., \& Lee, K.-W. (2006). A study of knowledge internalization: from the perspective of learning cycle theory. Journal of Knowledge Management, 10(3), 57-71.

Yang, J.-t. (2007). The impact of knowlegde sharing on organizational learning and effectiveness. Journal of Knowledge Management, 11(2), 83-90. 
Zack, M. H. (1999). Managing Codified Knowledge. Sloan Management Review, 40(4), 45-58.

Zack, M., Mckeen, J., \& Singh, S. (2009). Knowledge management and organizational performance:an exploratory analysis. Journal of Knowledge Management, 13(6), 392-409. 